If You're Going Through Hell, Keep Going: Non-linear Effects of Financial Liberalization in Transition Economies

\author{
Christopher A. Hartwell \\ Department of International Management \\ Kozminski University \\ ul. Jagiellonska 57-59, 03-301 Warsaw, POLAND \\ and \\ Center for Social and Economic Research (CASE) \\ Warsaw, POLAND \\ M: +48 538175826 \\ chartwell@kozminski.edu.pl; Christopher.hartwell@case-research.eu
}




\title{
If You're Going Through Hell, Keep Going: Non-linear Effects of Financial Liberalization in Transition Economies
}

\begin{abstract}
Did increasing the level and pace of financial liberalization during transition expose countries to crises? And if a crisis did strike, did liberalization do more harm or good? Using a database of 28 transition economies over 22 years, this paper examines these questions across a host of economic outcomes, including savings and the size of the private sector. The results provide evidence that, while liberalization may initially increase the probability of a crisis, the prospect of a crisis drops dramatically at higher levels of financial openness. Moreover, the benefits of liberalization across several metrics outweigh the risks of these intermediate stages.
\end{abstract}

JEL classification: P21, O17, G20

Keywords: Financial liberalization, institutions, property rights, non-linearity, banking crises 


\section{Introduction}

Financial liberalization has been part and parcel of the transition to capitalism in Central and Eastern Europe (CEE) and the former Soviet Union (FSU). This process of financial opening entailed both extensive internal reforms (freeing interest rates and allowing foreign and private bank entry) and external reforms (liberalization of the capital account) occurring simultaneously with the transition of the rest of the economy. But did the dual processes of financial liberalization assist or hinder the broader transition? On the one hand, modern financial systems were necessary for establishing a market economy, and a long line of work has established that financial sector liberalization in transition economies facilitated the expansion of credit to the private sector (Cottarelli et al. 2005), development of sound banks (Fries and Taci 2002), and, in conjunction with efficient institutions (Coricelli and Maurel 2011) or governmental fiscal and monetary responsibility (Berglof and Bolton 2002), sustained economic growth. On the other hand, the sequence and speed of financial liberalization also appeared to expose these countries to volatility from international financial markets and exacerbated the instability that accompanied the transition process.

So which effect predominated? That is, was the probability or severity of a crisis related directly to financial liberalization (as suggested in, among others, Kaminsky and Reinhart (1999)), or was the relationship non-monotonic? And in either case, did the financial crises, when they occurred, affect economic outcomes negatively in the long-term for transition economies? This task is made more interesting by the simple fact that the transition countries have not behaved as a monolithic bloc in their financial sector liberalization policies. For countries such as the Czech Republic and Slovakia, liberalization of the financial sector occurred rapidly and was predicated 
on the entry of foreign financial institutions, while others such as Tajikistan and Kazakhstan have either liberalized haltingly or have opened their doors only to banks from the neighborhood (mainly Russian). Thus, differential policies of liberalization should have translated into differential effects in generating crises and their severity.

This paper seeks to answer these two questions, empirically examining the effects of financial liberalization in first altering the probability of a banking crisis in transition, and secondly, in generating unfavorable economic outcomes. More importantly, using data from 1989-2011 for 28 transition economies, this paper explores the reality of non-linearities in the relationship between financial liberalization and financial crises. The results shown below support the idea that there is a consistent non-linear relationship between both financial liberalization and crises and the effect of financial liberalization and several successful economic outcomes; while liberalization may increase the likelihood of a crisis from the outset of transition, on average financial liberalization is much better for an economy than not liberalizing.

This paper elbows its way into the crowded literature on financial liberalization to offer three novel contributions to the literature. In the first instance, an examination of non-linearities in financial liberalization in transition economies exclusively has not, to my knowledge, been done in the extant literature. This is a missed opportunity, given the relative speed of financial liberalization in the various transition economies relative to other emerging markets, and thus we would expect to see any effects (including non-linear ones) accrue much more quickly. Secondly, this paper breaks new ground by examining the effects of financial liberalization on a whole host of economic indicators, moving beyond an obsessive focus with the relationship 
between financial liberalization and GDP. In fact, I assert that the other metrics I will examine in this paper, especially growth of investment and expansion of the private sector, are more important indicators of success in transition, especially in relation to the financial sector. Finally, this paper takes advantage of a broad series of indicators for financial liberalization, separating out the external and internal liberalization process in a methodological manner to clarify the differing facets of liberalization. The comprehensive nature of this examination adds conceptual clarity to an issue that has unfortunately been muddied by imprecise terms and their usage.

\section{The Link Between Financial Sector Liberalization and Crises}

Financial liberalization is commonly understood to consist of two related but exclusive components, one 'internal' and one 'external.' 'Internal' liberalization often refers to the dismantling of governmental regulations designed for financial repression of the domestic banking system (McKinnon 1980), including interest rate liberalization, private sector competition, and bank solvency guidelines. Conversely, 'external' liberalization refers more to the policy stance on capital flows, and whether or not a country is open to international capital movements, has an absence of capital controls, allows banks to raise funding on international capital markets, and other attitudes towards the financial sector vis a vis the world. While it is often the case from a policy standpoint that these two facets of financial sector liberalization go hand-in-hand, there are many examples of internal reform being undertaken first and capital account liberalization being slowly phased in afterwards (see Johnston et. al 1999).

The theory relating financial liberalization to financial fragility has focused on both of these facets of liberalization to varying degrees, mixing both internal and external liberalization 
uneasily an failing to 'specify a clear theory-based hypothesis for the relationship between the level of financial liberalization and banking crises' (Angkinand et. al 2010:265). Much of the theoretical work that has been done has contained an explicit focus on the negative effects of the differing facets of liberalization on the real economy in emerging markets. For example, internal liberalization has been linked with a raising of the risk profile of a banking system through interest rate liberalization (Daniel and Jones 2007 model this explicitly), exposure to maturity and interest rate risk with the removal of credit constraints (Weller and Morzuch 2000), and over-lending or lending done without heed to due diligence (as noted in the case of Indonesia in Bennett (1995)). Similarly, external liberalization has been extensively covered in the literature, as freeing capital accounts could overwhelm nascent banking institutions, take away policy sovereignty, or necessarily lead to sub-optimal lending or investment decisions by domestic banks.

However, despite these possible risks would come with financial sector liberalization, there are several factors which may make liberalization (of both types) insulation against a crisis. In the first instance, many of the 'risks' that are cited above are beneficial effects one would hope for in the long-run for an economy: risk-taking should be priced appropriately using market interest rates (which would then improve the intertemporal allocation of capital), and the loss of policy sovereignty in many countries would be a blessing, given the usage of repressed financial sectors to fund public sector and politically-connected firms (Diaz-Alejandro 1985). Beyond these obvious benefits, the freeing of the financial sector would be expected to encourage savings and better allocate credit (Fry 1997), as well as allow firms to access credit as financing frictions are 
reduced (Laeven 2003). All of these results would contribute to a stronger and more fundamentally sound economy, which would then mitigate banking risks.

These trade-offs suggest that there may be a non-linear relationship between financial liberalization and the probability of a crisis, following a Kuznets curve dynamic: the initial stages of financial opening (both internal and external) can increase the probability of a banking crisis, but higher levels of liberalization will create a sturdier banking system ceteris paribus, one that is more resilient and less likely suffer an endogenously-generated crisis. That is, the current theory relating risks to liberalization may not be a matter of risk versus reward so much as an issue of sequencing: that is, all of the risks inherent in internal and external liberalization are indeed present, but have a higher probability of occurrence when the learning curve is steep, diminishing over time as liberalization alters future institutional and financial paths. Such a nonlinear relationship would explain why pervasive regulation and state ownership can prevent banking crises, as countries such as North Korea have done fairly well at insulating themselves from financial turmoil. This could also explain why countries taking steps to emerge from financial liberalization see higher incidence of crises at first, but (hopefully) less as time passes and reforms progress. There also may be a differential effect of liberalization on the incidence of crises: internal liberalization may raise the probability of a crises less than external liberalization, but external liberalization before internal liberalization is complete may increase the prospects of a crisis.

Moreover, even if these changes in the economy were not enough to prevent a banking crisis from occurring, either due to exogenous shocks or poor due diligence and lending behavior, the 
adjustment mechanisms in a liberalized financial sector can be expected to operate much more swiftly than in a repressed financial sector (as in, for example, working out of distressed assets or mergers/consolidations of failing banks). In the words of Angkinand et. al (2010:270), liberalization means 'banks are subject to market discipline providing incentives for improved governance, risk management, and innovation.' Additionally, relaxing constraints on foreign bank entry would 'promote the stability of the domestic deposit base, and thus the stability of domestic banking and financial system, because they are less susceptible to domestic economic shocks’ (Yilmaz, Yabasakal, and Koyuncu 2009:3). Thus, if a shock were to occur, the presence of foreign financial institutions in a liberalized financial sector would help to guarantee a deposit base for continued lending and cushion the effects of a domestic disruption.

Finally, there may be a benefit to financial liberalization in regards to crises that accrues specifically to transition economies. Attitudes towards financial liberalization are often caught up with the entire range of reforms that a transition economy is undertaking, meaning that a government's policies in financial liberalization are also often similar to the policies they pursue in price, trade, and goods market liberalization as well. As Demirgüç-Kunt et al. (2004:539) correctly note in a different context, 'bank regulations cannot be viewed in isolation; they reflect broad, national approaches to private property and competition.' Thus, financial sector liberalization in transition would also signal the removal of other distortions in the transition to market, which in turn strengthens an economy at both the micro- and macro-level.

\section{Literature Review: Previous Research in Financial Liberalization and Volatility}


The empirical evidence on the link between financial liberalization and crises is extensive and, as noted by Demirgüç-Kunt and Detragiache (2001), tends to break into two separate streams, one focusing on the likelihood of financial crises due to financial reform and the other examining the link between financial sector liberalization and improved economic outcomes. Uniting these two streams in the context of transition is the goal of this paper.

\section{Liberalization and Probability of a Crisis}

Demirgüç-Kunt and Detragiache (2001) were one of the earliest to model the likelihood of financial crises in the face of liberalization, using a multivariate logit model covering 53 countries (both developed and developing) from 1980-95 to find that banking crises are indeed more likely in their sample for financially liberalized countries. However, perhaps more importantly, they also found that the gains from liberalization were higher than the risk of fragility for financially repressed countries (albeit with methodological caveats). Finally, they also found that the relevant institutional frameworks can mitigate the risk of a crisis, with respect for contract enforcement leading to less banking fragility.

Mehrez and Kaufmann (2000) came to similar conclusions about the institutional frameworks necessary to support successful financial reform, examining how transparency, loosely defined as a lack of corruption or perceptions regarding the government's communication of its policies, affected the probability of a financial crisis. Using a multivariate probit model for 56 developed and developing countries over 1977-97, they report a higher probability of a crisis during the five years following financial liberalization. In line with earlier research, they also find that the likelihood of a crisis is higher in countries that have poor transparency than in countries that are 
more transparent. This research was supported by Ranciere et al. (2006), who fashioned a model that decomposed the effect of financial liberalization on growth into a direct growth channel and an indirect 'fragility channel.' Expanding the examination of crises to 60 countries (also both developed and developing) over 1980-2002, they concluded that 'financial liberalization typically leads to financial fragility and occasional financial crises. In net terms, however, financial liberalization has led to faster long-run growth’ (Ranciere et al. 2006:13).

More recent research has supported these results, with Shehzad and De Haan (2009) using multivariate probit modeling over a much longer time frame (1973-2002) to find that financial reform in general reduces the likelihood of systemic crises, in addition to its benefits in growth. As a political economy corollary to these results, they also find that initial reforms lead to a virtuous cycle of further reform, which in turn increases the stability of the financial sector and makes it even less susceptible to crisis. Angkinand et. al (2010) reinforced these results, showing that 'the common view that financial liberalization leads to an increase in the likelihood of banking crises is not robust.' They also bring the financial crisis research full circle by noting that intermediate levels of liberalization appear to be the worst for fostering crises, but general institutional quality has a significant negative effect on the probability of banking crises for all of the countries in their sample.

\section{Liberalization and Crises: the Aftermath}

This broad literature examining the probability of a crisis as a function of financial liberalization, but an additional question of note is how financial liberalization affects economic outcomes if a crisis does occur. By contrast with the previous literature, the research into the linkages between 
financial liberalization and the effects of a crisis is comparatively thinner, with an emphasis on external liberalization rather than internal. Bonfiglioli and Mendicino (2004) noted that the adverse effects of banking crises seem to be less in countries that have liberalized externally (i.e. that have open capital accounts), while Ranciere et al. (2006:31) empirically show that the "direct growth gain of financial liberalization significantly outweighs the growth loss associated with more frequent financial crises." Kose et. al (2009:8) summed up the empirical evidence to this point as 'there is little systematic evidence to support widely-cited claims that financial globalization by itself leads to deeper and more costly developing country growth crises.'

Theoretical heft has been given to this idea in Gayton and Ranciere (2006) and Daniel and Jones (2007), who show that there are also non-linearities in the effects of financial crises related to liberalization; in both papers, it is shown that "middle income" countries or countries with intermediate levels of liberalization suffer more due to a financial crisis than do poorer or richer countries. There is even evidence of this effect from the transition literature (Furceri and Zdzienicka (2011), where results showed that continued financial liberalization worked as a possible way to mitigate against future shocks. Thus, even if transition had exposed the countries of CEE and FSU to the possibility of financial crises, perhaps the cure was to continue liberalizing; or, in the words of Winston Churchill (and the title of this paper), "if you're going through hell, keep going.”

\section{Data and Methodology}

Does Liberalization Make a Crisis More Likely? 
In order to test these two questions, I have amassed a database of 28 transition economies ${ }^{1}$ from 1989-2011 compiled from World Bank and Global Insight data. Transition economies were chosen because they were all subjected to numerous financial crises over the past 20 years, both at a country- and regional-level. ${ }^{2}$ Indeed, financial crises hit in both seemingly isolated incidents (such as the Czech Republic in the late 1990s and Slovakia from 1998 to 2002) and in broad, multi-country waves such as the Russian ruble crisis in 1998-99 and the global financial crisis of 2008-2010 (Table A.1 in the appendix shows a list of banking crises in transition, derived from Laeven and Valencia's (2012) database of crises). While part of this reality may have been attributable to the transition process itself, the fact that there was a differing pace of financial sector development across the transition space (Bonin and Wachtel 2003 and Bonin and Schnabel 2011) means that it is probable that variables shown in the broader research to influence the likelihood of a crisis would also hold true in the transition laboratory.

Following in the steps of Demirgüç-Kunt and Detragiache (2001) and Angkinand et. al (2010), the baseline specification for determining the likelihood of a banking crisis is:

$$
\text { (1) } \ln \left(\frac{p_{i t}}{1-p_{i t}}\right)=\alpha+\beta F I N L I B_{i t}+\theta F I N L I B_{i t}^{2}+\delta I N S T_{i t}+\gamma M A C R O_{i t-1}
$$

Where

$$
p_{i t}=\operatorname{Prob}\left(\operatorname{CRISIS}_{i t} \mid X\right)=\frac{1}{1+e^{-\left(\alpha+\beta F I N L I B_{i t}+\theta F I N L I B_{i t}^{2}+\delta I N S T_{i t}+\gamma M A C R O_{i t-1}\right)}}
$$

\footnotetext{
${ }^{1}$ The countries included in this dataset are Albania, Armenia, Azerbaijan, Belarus, Bosnia, Bulgaria, Croatia, Czech Republic, Estonia, the Former Yugoslav Republic of Macedonia, Georgia, Hungary, Kazakhstan, Kyrgyzstan, Latvia, Lithuania, Moldova, Mongolia, Poland, Romania, Russia, Serbia, Slovakia, Slovenia, Tajikistan, Turkmenistan, Ukraine, and Uzbekistan.

2 This was in direct contrast to the experience under communism, where there were no 'financial crises;' given the administrative role of banks in the socialist economy, financial crises were really governmental or budget crises and not bank runs, losses in the banking system, and/or bank liquidations. Thanks to an anonymous referee on an earlier version of this draft who noted the somewhat obvious lack of financial crises in the Soviet Union, but not the also obvious cause of this fact.
} 
The multivariate logit model shown in Equation 1 is estimated as both a maximum-likelihood model with country clustering and a population-averaged model in order to avoid the issue of having countries without crises being dropped under a fixed-effects specification. ${ }^{3}$ Additionally, the population-averaged specification (as used in Büyükkarabacak and Valev (2010)) allows for the use of Huber/White sandwich robust standard errors.

The dependent variable in Equation 1 is probability of a banking crisis, based on the reality that banking crises are almost wholly tied into the progress of financial liberalization (as well, of course, as other external factors). By contrast, inflationary episodes, exchange rate crashes, and sovereign debt defaults may both be transmitted and amplified by the financial sector, but these types of crises never wholly originate within the financial sector, nor does financial sector liberalization purport to be the main cause of any of these governmentally-based crises. Transition economies also tend to be heavily reliant on bank-based lending, meaning that bank crises are more likely to have an effect on the real economy (an effect confirmed by Hutchison and Noy (2005), who find that banking crises harm output growth more than currency crises).

Focusing exclusively on banking crises, I use the Laeven and Valencia (2012) database of 'systemic' banking crises over the past 35 years (with one additional change for Tajikistan in 1996 taken from Caprio et. al 2005). A commonly-utilized coding of a crisis, Laeven and Valencia (hereafter LV) define a 'systemic' banking crisis as the first year that both significant signs of financial distress in the banking system (as indicated by significant bank runs, losses in

\footnotetext{
${ }^{3}$ Additionally, random-effects was chosen over a population-averaged model so that the random intercept can capture the combined effect of all omitted country-specific covariates that may cause these countries to be more prone to crisis.
} 
the banking system, and/or bank liquidations) and significant banking policy intervention measures in response to significant losses in the banking system are present. As in Angkinand et al. (2010), the crisis dummy is set to 1 in the year that a crisis occurs, and 0 if a crisis did not occur that year.

Babecky et al. (2014) correctly note that there are problems with the LV coding, mainly related to the judgement call on the end of a crisis and the overall definition of a crisis (as pre-emptive public intervention that averts a crisis would be coded as a crisis in the LV dataset). However, alternate datasets have much lower coverage for transition economies: Caprio et al. (2005) have a large number of transition countries in their database, but include only Russia and Ukraine from the former Soviet Union, while their data only runs through 2002. Kaminsky and Reinhart (1999) have a monthly dataset but for only 26 countries (smaller than our current dataset) and Reinhart and Rogoff (2009) only cover four transition economies up until 2008. Even the Babaecky et al. (2014) dataset, measured at a quarterly frequency, contains only current EU members from CEE, with no coverage for the former Soviet Union. More importantly, there are only slight discrepancies in the coding across datasets: Babecky et al. (2014) code Bulgaria as having a crisis in 1994 through 1997, while LV have it only from 1996 to 1997, and Reinhart and Rogoff (2009) note that Russia had a banking crisis in 1995, while LV only recognize a crisis in 1998. The prospect of LV undercounting crises during times of liberalization will be accounted for in the empirical analysis below.

Similar issues will be encountered in measuring the financial liberalization of a country (FINLIB in Equation 1). In regards to 'internal liberalization,' I focus on the EBRD's transition indicator 
of bank reform, which captures major measures of internal liberalization (including interest rate policies and bank competition) on a scale from 1 to 4.33 (higher being better). The EBRD indicator has much to recommend it, including a time series back to 1989 for all transition economies, and it has been a common gauge of transition progress in the financial sector. There are also issues inherent in using such an objective indicator however, as pointed out by Campos and Horvath (2012:229); in the first instance, much like the crisis indicator, "policy inputs as well as policy outcomes" may be included in the EBRD rating, while the indicator may also be prey to revision even though the underlying data may not have changed. A further problem with the EBRD index worth stressing here is that it captures convergence to Western European standards, rather than necessarily capturing absolute liberalization. This can be problematic for understanding where transition countries are beyond a scale from zero to Western Europe, especially given the heterogeneity in Western European financial systems which resist a common characterization (Nicoletti and Scarpetta 2003).

To account for these possible issues in the liberalization indicator, I utilize an alternative objective measures for internal liberalization, the ratio of deposit money bank claims on the domestic nonfinancial real sector to the sum of deposit money bank and Central Bank claims on the domestic nonfinancial real sector. This indicator is taken from Beck and Demirgüç-Kunt (2010) and countries with higher ratios of deposit money bank claims as opposed to central bank claims will exhibit higher levels of financial freedom (and liberalization). While neither this indicator or the EBRD index is perfect on its own as a proxy for internal financial liberalization is perfect on its own, utilizing the two measures in tandem can be effective in helping to isolate the effect of liberalization. 
In order to quantify external financial liberalization, I will focus on the Chinn-Ito (2008) indicator of financial openness, which takes on higher values the more open the country is to cross-border capital transactions, with a mean (across all countries) of zero and a range in practice of -1.86 to 2.46 (Chinn and Ito 2008). Additionally, as the Chinn-Ito indicator is a collection of subjective measures, I will check it with an objective indicator for external liberalization, namely the share of foreign bank claims in the economy. As Naaborg et. al (2004) has noted, the presence of foreign banks in transition economies has been a prime determinant of their financial sector development, while the proportion of foreign bank involvement has correlated strongly with less crises (Tschoegl 2005, Yilmaz et al. 2009). I anticipate this relationship to hold here, with the presence of foreign banks acting as an indicator for external liberalization.

Finally, as mentioned above, there are strong theoretical possibilities of non-linearities related to financial liberalization, a trend that is confirmed in Figure 1, which matches the number of crises occurring by level of liberalization (as captured by the EBRD bank indicator). In order to capture these non-linearities, a quadratic term of liberalization for all objective and subjective indicators will be included, as shown in Equation 1.

Figure 1 - Number of Banking Crises, by EBRD Banking Reform Level 


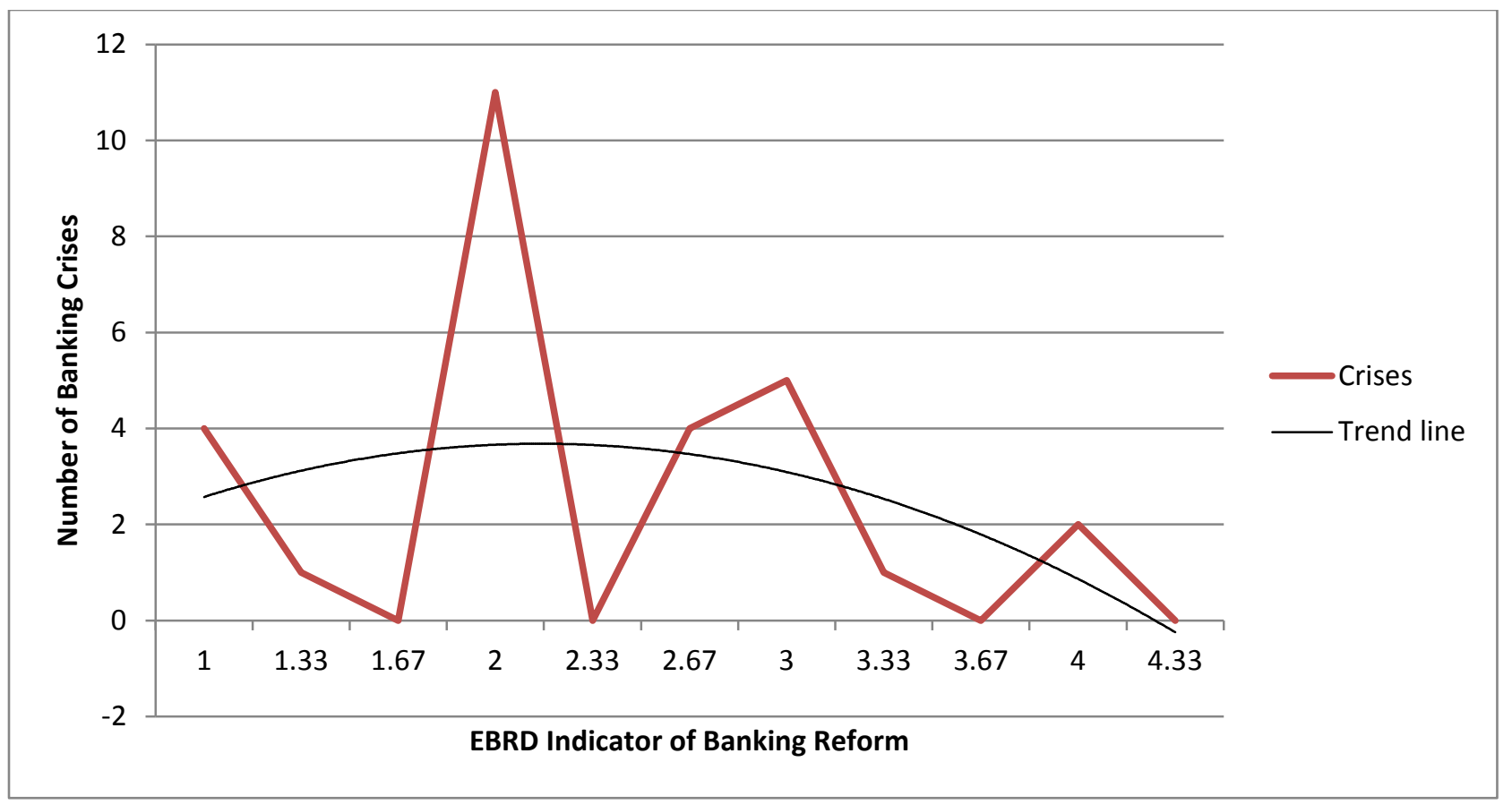

The macro variables utilized as a control in the analysis of Equation 1 will be similar to Angkinand et. al (2010), with slight variations to account for advances in institutional measurement. In particular, I will utilize a parsimonious model of macro variables more in line with Demirgüç-Kunt and Detragiache (1998) and found to have an association with banking crises, including log GDP per capita (Kaminsky and Reinhart 1999), inflation (Eichengreen and Rose 2004) ${ }^{4}$, extent of deposit insurance (Demirgüç-Kunt et. al 2008) ${ }^{5}$, and bank credit as a percentage of GDP. On this last indicator, bank credit is often utilized in the literature as a proxy for financial sector liberalization or depth (see Pill and Pradhan 1995). However, in my estimation this is an incorrect usage in the transition context, where large swathes of the financial sector may still be state-owned and yet state-directed; thus, credit levels may be rising but the financial sector is no more 'liberalized.' Instead, given its role as a prime culprit in the global

\footnotetext{
${ }^{4}$ As in Hartwell (2013), I utilize the logarithmic transformation of log (100 + inflation rate) in order to smooth out the rather large changes in inflation that occurred during transition.

${ }^{5}$ Given that the commonly-used Demirgüç-Kunt et al. (2008) indicator only runs through 2003 , I have painstakingly updated and extended the time series of deposit insurance coverage through 2011 for all transition economies.
} 
financial crisis and a proven determinant of banking crises (also Pill and Pradhan 1995), this indicator will be used in this paper to proxy for indirect monetary policy effects, as well as financial maturity. ${ }^{6}$

These controls are included at their first lag to eliminate reverse causality and trace the line from liberalization to crisis, apart from deposit insurance (which should theoretically mitigate against a crisis in the current period). Finally, given that "institutions matter," I also include an additional explanator for institutional quality, the International Country Risk Group’s (ICRG) annual ranking of "investor protection." ${ }^{7}$ This indicator is an index that covers three subcomponents (contract viability/expropriation, profit repatriation, and payment delays), each with a maximum score of four points and a minimum score of 0 points, for a total of 12 (with higher scores signifying more property rights). The ICRG indicator will be included without lags, as I hypothesize that not only can a stronger institutional environment help to guard against crises in the future, but they may also help to prevent an economic disruption from rising to the level of a crisis.

\section{Does Exposure to a Crisis Even Matter?}

While Equation 1 goes over somewhat familiar territory in terms of relating bank crises to financial liberalization, I will also examine the performance of several economic indicators in periods of crisis as a function of financial sector liberalization and other institutional factors:

(2) $Y *_{i t}=\alpha F I N L I B_{i t}+\rho F I N L I B_{i t}^{2}+\beta I N S T_{i t}+\gamma M A C R O *_{i t}+\delta C R I S I S_{i t}+\theta I C 1_{i t}+$

$$
\mu I C 2_{i t}+e_{t}
$$

\footnotetext{
${ }^{6}$ Sensitivity tests on other macroeconomic variables featuring in the literature will be used in the next section.

${ }^{7}$ The use of this index will provide a more nuanced approach to institutional quality than in Angkinand et. al (2010), who use log of real GDP per capita to proxy for institutional effects.
} 
Where

$$
e_{t}=\rho e_{t-1}+\varepsilon_{t}
$$

Equation 2 thus models several success metrics $(\mathrm{Y})$ as a function of financial liberalization (as well as non-linearities), other relevant institutions (INST), macroeconomic variables derived from previous literature (MACRO), a dummy variable for years that a banking crisis occurred (CRISIS), and two initial conditions indicators.

As in Hartwell (2013), the expansion of the Y variable beyond GDP is a key tenet of this paper. The prior literature has focused almost exclusively on the effects of crises on growth, which, in a transition context, is a bit misleading, as GDP growth is merely a second-order effect of transition after other preconditions have been fulfilled. Thus, this paper focuses on a broad range of economic 'success metrics,' including private sector share of GDP, FDI inflows, and per capita savings rate (see Table 1), as the Y variables in Equation 2. In theory, a more efficient and open financial sector should lead to better financial intermediation (i.e. enabling resources to move from lower- to higher-valued activities), a larger private sector/more investment, and thus more resilience to a crisis. Of course, GDP growth will be included as a robustness test, but to focus on GDP exclusively is to miss the point of transition.

In regards to the independent variables, a rich literature exists on the effects of initial conditions on the transition path of the economies of CEE and FSU, including but not limited to de Melo et. al (2001), and Havrylyshyn and van Rooden (2003). The initial conditions clusters IC1 and IC2, derived from principal components analysis (as shown in Table 2) and based on work from de 
Melo et. al (2001) will proxy for fixed-effects amongst countries and the initial distortions that were present at the beginning of transition. Given the composition of the two clusters, we would expect to see cluster IC1 have lower scores as a more desirable outcome (that is, less of a black market exchange premium, less represses inflation), while there should be an overall positive correlation between the IC2 cluster and metrics of success. ${ }^{8}$

As above, the investor protection indicator from ICRG will be used as an institutional control. Additionally, in some areas, it may be necessary to dig deeper into the institutional framework and examine an objective measure of property rights as a robustness check on institutional quality; to address shortcomings in the ICRG index, I will also use property rights as calculated as in (among others) Clague et. al (1996) and Hartwell (2013) as 'contract-intensive money,' defined as

$$
\text { (3) } \frac{\left(M_{2}-C\right)}{M_{2}}
$$

Where M2 is a broad definition of money supply and C is the amount of currency held outside of formal financial institutions. As Clague et. al (1996) demonstrate, variation in this indicator across countries tracks actual changes in institutions and policies, and thus may be empirically more reliable than subjective data regarding property rights enforcement. ${ }^{9}$

\footnotetext{
${ }^{8}$ The further advantage of the clustering approach, as de Melo et. al (2001:17) note, is that this use of principal components "reduce[s] the dimensionality of the initial conditions variables" and deals with multicollinearity of the constituent variables in a much more effective manner. Additionally, they also correctly note that initial conditions often "exert their effect jointly, so that the individual approach suffers from the omitted variables problem and results estimated coefficients that are biased."

${ }^{9}$ While contract-intensive money is an objective indicator for property rights, this indicator might also catch some effects of financial sector efficiency (that is, the amount of money held outside of formal financial institutions may be due to the failings of a country's financial sector instead of the entire institutional system). Even if this is the case, however, as an instrument it is still theoretically sound: the failures of a financial sector could be expected to determine the government's stance on financial sector liberalization in the following period. I also believe that any financial sector effects it could capture would be more than overwhelmed by the systemic issues (and approach to property rights) that it is meant to represent.
} 
As earlier, the crisis dummy is taken from Laeven and Valencia’s (2012) database of banking crises, with the exception that, in this specification, we are looking for the effect of both the length and duration of a crisis. Thus, from Equation 2 onward, the crisis dummy will be coded at 1 for every year in which there is a crisis (whether it began in that year or not) and 0 for every year that did not have a banking crisis, unlike earlier when it was coded 1 only for the onset of a crisis. ${ }^{10}$ Where appropriate, and given that the effects of a crisis may be felt farther out than during the period in which it begins, I will also include lags of the crisis dummy to correct for their long-term legacy. This approach also reduces somewhat the problem of endogeneity in the analysis (which I will discuss further below).

The macroeconomic control variables for Equation 2 will not be uniform across the regressions, but instead will be based upon the specific metric of success and previous literature. For private sector size, inflation (-), the size of government as percentage of GDP (-), and the lag of the GDP growth rate $(+)$, as well as a dummy for EU accession $(+)$ to capture effects of convergence to Western European institutions, are included. In regards to FDI, based on the prior literature noted above, we include inflation (-), share of government's role in the economy (-), and the (log of) the total external debt stock of a country (-) as control variables, as well as an EU dummy to capture the effects of anticipated EU accession (+). Finally, as there is an extensive literature regarding determinants of saving in transition, I have chosen a range of macroeconomic variables proven to be significant, including the real interest rate (which, as Osoian et. al (2008) note, would have an ambiguous effect on savings due to income and substitution effects), the

\footnotetext{
${ }^{10}$ This distinction means that, although similar, Equations 1 and 2 differ slightly and are not simultaneous. The use of methods for solving simultaneous equations, such as maximum likelihood, would thus be inappropriate.
} 
dependency ratio (Chowdhury 2004, likely to be negative), and the ratio of M2 to GDP, to capture the level of monetization of the economy.

The estimator used in Equation 2 for all of these $\mathrm{Y}$ variables is a Prais-Winsten regression with panel-corrected standard errors to control for heteroskedasticity and autocorrelation issues; in particular, the persistence of correlation of the standard errors will be mitigated through panelspecific AR(1) transformations. As a final check on these results, and as many have noted (Rousseau and Wachtel 2011), there is almost a certainty that financial sector institutions in transition economies are endogenously determined. Moreover, the very argument made in the first half of the paper is that financial liberalization influences the incidence of a crisis, and thus inclusion of a crisis dummy would be endogenous on prior periods of liberalization. This will be controlled for using a two-step instrumental variable-generalized method of moments (IV-GMM) estimation, extensively utilized in the financial liberalization literature (see, as just one example, Joyce and Nabar 2010). ${ }^{11}$

As a final diagnostic, despite the similarity in some of the variables (in that they are all measuring some facet of financial sector development, implicitly or explicitly), multicollinearity is not a problem within the data itself. The correlation matrix shown in Table 3 shows that the correlations amongst all the independent variables are not very strong, with the highest correlation being the fact we noted above, that external and internal liberalization tend to go in tandem. However, given that even this correlation is somewhat low (0.60), we can be satisfied that multicollinearity is not present in the analysis.

\footnotetext{
${ }^{11}$ The exigencies of our panel dataset also makes GMM a good choice; in the first instance, the dataset has a shorter time dimension ( $t=21$ or 22 ) than country panels $(n=28)$, a problem which the GMM estimator was designed for.
} 


\section{Results}

Results: Does Liberalization Make a Crisis More Likely?

The results of the multivariate logit regression are shown in Table 4, detailing the maximumlikelihood specification including all control variables, as well as a control marginal effects (population-averaged) specification. Columns 1, 3, 5, and 7 utilize the EBRD subjective indicator to proxy for internal financial liberalization, while Columns 2, 4, 6, and 8 utilize the deposit money indicator noted above. Columns 1, 4, 5, and 8 include the Chinn-Ito capital control indicator, while 2, 3, 6, and 7 use the objective indicator of foreign bank claims instead to proxy for external liberalization.

The results across all specifications and utilizing both subjective and objective indicators appear to confirm our hypothesis of the non-linear nature of liberalization on a banking crisis. Internal liberalization, as measured by the EBRD indicator, is consistently and significantly associated with a higher probability of a bank crisis, while the quadratic term for the EBRD indicator is consistently negative. ${ }^{12}$ However, this relationship only holds for the subjective indicator of internal liberalization: using deposit money assets as an indicator, we see a marginal but negative influence of liberalization on a banking crisis. This apparent contradiction can be explained in terms of what the different indicators are capturing, in that the EBRD indicator ranks potential liberalization (in the sense of the legislative framework for financial liberalization), while the

\footnotetext{
${ }^{12}$ Additional regressions, not reported, show similar results no matter which coding of a crisis is utilized. The only discrepancy occurs when utilizing the Reinhart and Rogoff (2008) coding for Poland and Russia, which lessens the significance of the EBRD indicator from $1 \%$ to $5 \%$ and halves the economic significance. Utilizing the Babecky et al. (2014) coding yields only slight changes in magnitude but no changes in statistical significance.
} 
deposit money indicator captures realized liberalization (in the sense of the outcomes of internal liberalization).

For external liberalization, the results are clear-cut in terms of direction, if not in terms of magnitude, as both the subjective and objective indicator show a negative relationship with the probability of a banking crisis. However, the significance of this indicator is dependent upon the model specification, with marginal significance in the maximum-likelihood estimations and somewhat stronger significance in the population-averaged model. In no specification, however, is external liberalization correlated with higher probability of a banking crisis, comporting with the results of Shehzad and De Haan (2009) and Angkinand et. al (2010).

The results of the controls are, for the most part, as expected. The inclusion of deposit insurance is consistently correlated with higher probability of a crisis, although whether this means it creates moral hazard and encourages a crisis or is merely capturing other effects, I cannot say here. Property rights also perform exactly as expected, with higher levels of rights significantly correlated with lower probability of a crisis. The lag of inflation somewhat paradoxically enters the models, in all specifications, as negative (although insignificant in one regression), perhaps suggesting again that countries with high levels of macroeconomic mismanagement do not need to worry about banking crises, as their banking sectors are just one of many distortions.

Finally, as a check against the endogeneity of financial liberalization in this specification, a twostep instrumental variables probit (IV-probit) regression in the manner of Shehzad and De Haan (2009) is used in Column 9 for the subjective indicators of liberalization. It is plausible that 
initial conditions and institutions can influence the choices for financial liberalization; that is, the path of financial liberalization is determined by where the financial system began in transition, as well as the distortions that existed economy-wide. To incorporate this path dependence, I instrument the two financial liberalization indicators with the two initial conditions clusters (described above), the level of financial system deposits in 1995 (the first year available for many countries), and the current level of property rights. Using this specification, the results for internal liberalization hold and remain concave, but it appears that external liberalization performs better as a result of instrumentation; capital openness is now a significant and negative explanatory of banking crises. This model also is the first to capture the "correct" sign of the bank credit control, which is a positive and significant determinant of a banking crisis.

\section{Results: Does Exposure to a Crisis Even Matter?}

If financial liberalization made transition economies less likely to experience a banking crisis, what happened when they did indeed experience a crisis? The results of the various specifications and models are shown in Tables 5-8, and the results are fairly consistent across the various success metrics: there is a strong correlation between financial openness and positive economic outcomes in three of our four dependent variables, even during crisis periods, and in the last metric (savings) there is some support for liberalization mitigating a crisis. ${ }^{13}$

The first success metric, size of the private sector, is shown in Table 5. The macro variables perform as expected, with inflation in previous periods leading to a lower private sector share of

\footnotetext{
${ }^{13}$ For each specification, a robustness test was attempted that included a full complement of time dummies; however, in every specification, the time dummies were insignificant and did not alter the significance of the main effects. Given the loss of degrees of freedom in the model from including 20 years of dummies, the results reported below do not have time dummies included.
} 
GDP, as does government size; growth is a positive contributor to the size of the private sector, while the EU dummy is almost wholly insignificant. Two measurements of property rights are used as well, given that the ICRG indicator has less coverage, but they both point to positive influence of property rights on the development of the private sector. More importantly, across every specification, internal liberalization is positive and (economically and statistically) significant correlates with a larger private sector. This result holds whether we measure internal liberalization by the EBRD indicator or the objective indicator of bank deposits as a percentage of GDP. Likewise, external liberalization as measured by capital openness is a positive (but smaller) force driving the private sector in every model (although the foreign bank claims measure is both insignificant and results in a large loss of observations). The quadratic terms for capital openness, as in the logit/probit estimations earlier, also show no non-linear effect. However, the quadratic term for internal liberalization is exactly the opposite as in the likelihood of crisis, in that it appears that internal financial liberalization increases the size of the private sector to a point, and then tapers off. Put together with the results from the first series of regressions above, it appears that private sector growth occurs most rapidly at the exact same time that crises are more likely, a reality that perhaps hell (in this case, a crisis) might have things to recommend it.

Turning to foreign direct investment (Table 6), I swap out the ICRG indicator for property rights with contract-intensive money from Equation 3, due to the low coverage of the investor protection index with this dependent variable. Including this proxy, we see that, on the whole, internal financial liberalization is mildly positively correlated with more FDI using the EBRD indicator, while positive and insignificant while using the objective indicator of bank deposits, 
controlling for times of crisis. ${ }^{14}$ The capital openness indicator is positive but insignificant across most specifications. For both facets of liberalization and both objective/subjective indicators, the quadratic indicators are insignificant, meaning that there are minimal non-linear effects. The controls mostly perform as expected, with both government size and external debt as negative correlates of FDI inflows, albeit only significant when paired with the subjective liberalization indicators. The key takeaway from this formulation appears to be that internal financial sector liberalization is a potential determinant of FDI net inflows, more so than even external openness, but the relatively poor specification of the model (and its low explanatory power) means that these relationships should be explored further.

Table 7 shows the final success metric, the per capita savings rate; due to reduced coverage of the investment profile indicator and this metric, as with FDI I have utilized the measure of contract-intensive money exclusively as a proxy for property rights. ${ }^{15}$ In most regressions, we see a significant negative effect of financial sector liberalization on savings (as in Bandiera et. al (2000)), with once again a non-linear relationship; savings decline as liberalization increases, but eventually bottoms out and increases at the highest levels of internal liberalization (this could be a function of the relationship between internal liberalization and banking crises as shown in the earlier section). On the other hand, capital openness and property rights are positive and significant explanators of savings rates (apart from the objective indicator of foreign bank claims, which is negative but statistically no different from zero), with external liberalization appearing to fill in the holes that loss of confidence in the domestic banking sector may have

\footnotetext{
${ }^{14}$ In a simple bivariate regression (not reported), the EBRD bank indicator is continually positively correlated with FDI (for all models, including FE, GLS, and PCSE), showing that this relationship isn't conditioned on choice of controls.

${ }^{15}$ This specification gives us almost one hundred more observations due to the low coverage of the ICRG index.
} 
opened. ${ }^{16}$ Inclusion of an interaction term of property rights and internal liberalization leads to perfectly zero effect on the model. ${ }^{17}$

Finally, turning to the instrumental variable regressions, we see the results in Table 8 of the IVGMM equations for all success metrics. The instruments chosen for each dependent variable are derived from the appropriate literature and diagnostics carried out throughout the regressions, with the best-fit results satisfying the assumptions of the IV-GMM estimator presented here. Given well-known endogeneity issues with growth regressions, I have held off from utilizing growth as a metric of success until now, but in Column 1 of Table 8 , growth is modeled as a function of internal and external financial liberalization, crises, and standard macroeconomic controls from the literature (investment, government size, secondary enrollment, and inflation) as a further robustness check. In this regression, the financial institutions are instrumented with the initial conditions of the specific country: specifically, the two initial conditions clusters from the Prais-Winsten regressions, the banking crisis dummy, and property rights. The results are broadly similar to other metrics of economic success, in that internal liberalization appears to have a negative linear effect on growth, but in reality is only negative until an inflection point. The exact opposite effect obtains for external liberalization, where external liberalization leads at first to growth gains but then a slowdown and reversal.

\footnotetext{
${ }^{16}$ The objective indicator for external liberalization showed as a poor fit in diagnostics. For this reason, I place more emphasis on the subjective models.

${ }^{17}$ Robustness checks performed in earlier versions of this paper, but not reported here, used lags of the crisis dummy out to a horizon of five years in order to capture long-term effects of banking crises. Given that the nonlinearity of liberalization means that immediate effects of liberalization should decay rather quickly, there should be less of an effect as time passes. The additional work done in earlier versions of this paper, not reported here, uniformly showed that the crisis dummy had little effect beyond a one-year window, while the effect of the liberalization indicators were unchanged.
} 
Turning from the cursory look at growth to our various success metrics, the results from the Prais-Winsten regressions in Tables 5-7 are replicated here. In regards to private sector size (Column 2), Durbin-Wu-Hausman tests of endogeneity revealed that financial liberalization was exogenous to this model, but property rights and, importantly, the crisis dummy were not. ${ }^{18}$ Thus, unlike in growth (or the other metrics of success), both facets of financial liberalization are retained as exogenous regressors and property rights and the crisis dummy are instrumented. Drawing from extensive work on the political factors that can instrument for property rights (Hartwell 2013), I instrument property rights and crises with the initial conditions clusters, as well as the EU accession dummy and two political indicators: the extent of democracy (taken from the Polity IV database) and the effectiveness of the legislature (taken from the CrossNational Time Series dataset, Banks and Wilson 2013). Under this specification, we see both a positive effect of internal and external liberalization, with a slight curvilinear effect at higher levels of liberalization. This fits intuitively, as private sector growth should be reliant in later stages on capital markets and less on banks (or reliant on foreign investors). In terms of controls, property rights have a strong positive effect again, and the incidence of a crisis has a significant negative effect on the development of the private sector.

Net FDI inflows (Column 3) once again shows a non-linear influence of internal liberalization (with flows increasing through the liberalization process but tapering at higher levels of liberalization), but the opposite effect for external liberalization. Interestingly, it appears that initial external liberalization leads to capital flight abroad, as investors search for safe havens, but higher levels of liberalization bring FDI back into the country.

\footnotetext{
${ }^{18}$ Using ivreg2 in Stata 13 with the command "orthog," the crisis dummy showed as exogenous in each of the other IV-GMM specifications. It was only with private sector size as a dependent variable that it was endogenously determined.
} 
Finally, in regards to savings (Column 4), other instruments were necessary to specifically capture the financial liberalization variables in this model. In addition to property rights and the crisis dummy, initial banking conditions (total assets of the banking system in 1995), initial conditions in the economy (GDP in 1995), and the extent of executive constraints (taken from Polity IV) are included. Additionally, a cultural, exogenous instrument is introduced, the proportion of the population that reports itself as Catholic. This is used as to capture the cultural effects that may influence savings, where Catholic teachings may encourage savings (this effect was observed in Guiso et al. 2006). In the IV-GMM specification, the results show a very strong curvilinear relationship for both internal and external liberalization, with an average negative effect on savings from financial liberalization but a concave upward relationship in the quadratic term. Thus, we can surmise that, not only are both facets of liberalization endogenously determined (as shown in Table 7), but that they have an initial negative impact on savings that turns positive at higher levels of liberalization. Once again, this links nicely with the results from the first set of regressions: if intermediate stages of liberalization are prone to more crises, it is less likely that individuals will increase savings in financial institutions in such an environment. It is better to wait until there is less chance of a crisis and losing it all. This too may be an effect of transition, a "wait and see" approach that is conditioned on the fact that the original transition had a negative effect on those holding communist currencies.

\section{Conclusions}

This paper has comprehensively examined the effects of internal and external financial sector liberalization in the transition economies of CEE and FSU, focusing on the question "has 
liberalization made the formerly socialist economies more susceptible to banking crises?” The results shown above provide evidence that, while liberalization and integration in international financial markets may increase the probability of a crisis at low levels of liberalization, once higher levels of liberalization are reached the prospect of a crisis drops dramatically. Indeed, the most dangerous time for a transitioning country is to be caught in a hybrid situation, where stateowned banks are operating alongside private ones or where there is still use of directed credit or interest rate ceilings.

Moreover, as the results of our examination of the effects of liberalization on several transition metrics show, the benefits of liberalization long-term outweigh the risks of passing through these intermediate stages, as liberalization can help to moderate the effects of a crisis if and when it does strike. These findings are consistent with previous literature for developing countries, but show a much stronger and highly significant correlation in transition economies.

These results also confirm earlier studies that draw a link between institutional quality and a crisis. Going further than earlier work, however, my two indicators for property rights show that stronger rights help to safeguard against the possibility of a crisis, as well as mitigate its effects. This is especially true in instrumental regressions, where property rights are a major determinant of the path of financial liberalization, which in turn leads to better economic outcomes.

The future research agenda from these results is promising and virtually limitless, as every passing year brings more data points and the transition continues. A key issue for future papers may be to formally theoretically model the distinction between exogenously-determined crises 
and endogenously-determined ones in transition, which could account for differential effects on economic outcomes. Similarly, an extension of this work beyond banking crises and into currency or debt crises (as in Babecky et al. 2014) would be useful.

On a final policy note, these results also argue for a completely different policy approach in transition economies to financial liberalization than the path many countries are now on. Since the global financial crisis, financial sector openness has taken a step back. The lessons from this

analysis again say that you shouldn't seek to stay in hell, but keep going. Steps backwards in financial liberalization in transition only heighten the probability of a crisis, rather than lessen it, and can make the effects of a crisis needlessly more protracted. Indeed, coupled with supranational regulations, the trend recently has been to retreat from the same traits that made transition economies able to weather crises. This may now make them more vulnerable.

\section{ACKNOWLEDGEMENTS}

The author wishes to thank Sergei Guriev, Nikolay Ushakov, Pok-Sang Lam, Shaomin Li, Taufiq Choudhry, and two anonymous referees for their extensive comments.

\section{REFERENCES}

Angkinand P. A., Sawangngoenyuang, W., and Wihlborg, C. (2010). Financial Liberalization and Banking Crises: a Cross- Country Analysis. International Review of Finance, 10(2), pp 263292.

Babecký, J., Havránek, T., Matějů, J., Rusnák, M., Šmídková, K., and Vašíček, B. (2014). Banking, debt, and currency crises in developed countries: Stylized facts and early warning indicators. Journal of Financial Stability, 15(1), pp. 1-17.

Bandiera, O., Caprio, G., Honohan, P., and Schiantarelli, F. (2000). Does financial reform raise or reduce saving? Review of Economics and Statistics, 82(2), pp. 239-263. 
Banks, A.S., and Wilson, K.A. (2013). Cross-National Time-Series Data Archive. Databanks International, available at: http://www.databanksinternational.com.

Beck, T., Demirgüç-Kunt, A., and Levine, R. (2010). Financial institutions and markets across countries and over time: The updated financial development and structure database. The World Bank Economic Review, 24(1), pp. 77-92.

Bennett, M.S. (1995). Banking Deregulation in Indonesia, University of Pennsylvania Journal of International Law. 16(3), pp. 443-481.

Berglof, E. and Bolton, P. (2002). The Great Divide and Beyond: Financial Architecture in Transition. Journal of Economic Perspectives, 16, pp.77-100.

Bonfiglioli, A., and Mendicino, C. (2004). Financial Liberalization, Bank Crises and Growth: Assessing the Links, SSE/EFI Working Paper Series in Economics and Finance No. 567, available at: http://swopec.hhs.se/hastef/papers/hastef0567.pdf.

Bonin, J. P. and Schnabel, I. (2011). The Great Transformation: From Government-Owned to Foreign-Controlled Banking Sectors. Economics of Transition, 19, pp. 397-405.

Bonin, J., and Wachtel, P. (2003). Financial Sector Development in Transition Economies: Lessons from the First Decade. Financial Markets, Institutions, and Instruments, 12, pp. 1-63.

Büyükkarabacak, B., and Valev, N. (2010). The Role of Household and Business Credit in Banking Crises. Journal of Banking and Finance, 34, pp. 1247-1256.

Campos, N., and Horvath, R. (2012). Reform Redux: Measurement, Determinants and Growth Implications. European Journal of Political Economy, 28(2), pp. 227-237.

Caprio, G., Klingebiel, D., Laeven, L. and Noguera, G. (2005). Appendix: Banking Crisis Database. In Honohan, P. and Laeven, L. (eds.), Systemic Financial Crises: Containment and Resolution, Cambridge, U.K.: Cambridge University Press.

Chinn, M. D. and Ito, H. (2008). A New Measure of Financial Openness. Journal of Comparative Policy Analysis, 10, pp. 309 - 322.

Chowdhury, A. (2004). Private Savings in Transition Economies: Are there Terms of Trade Shocks? Comparative Economic Studies, 46, pp. 487-514.

Clague, C., Keefer, P., Knack, S., and Olson, M. (1996). Property and contract rights in autocracies and democracies. Journal of Economic Growth, 1(2), pp. 243-276.

Coricelli, F., and Maurel, M. (2011). Growth and Crisis in Transition: A Comparative Perspective. Review of International Economics, 19, pp. 49-64. 
Cottarelli, C., DellAriccia, G., and Vladkova-Hollar, I. (2005). Early birds, late risers, and sleeping beauties: Bank credit growth to the private sector in Central and Eastern Europe and in the Balkans. Journal of Banking \& Finance, 29, pp. 83-104.

Daniel, B.C. and Jones, J.B. (2007). Financial Liberalization and Banking Crises in Emerging Economies. Journal of International Economics, 72(1), pp. 202-221.

De Melo, M., Denizer, C, Gelb, A., and Tenev, S. (2001). Circumstance and Choice: The Role of Initial Conditions and Policies in Transition Economies. World Bank Economic Review, 15, pp. $1-31$.

Demirgüç-Kunt, A. and Detragiache, E. (1998). The Determinants of Banking Crises: Evidence from Industrial and Developing Countries. IMF Staff Papers, 45(1), pp. 81-109.

(2001). Financial Liberalization and Financial Fragility. in G. Caprio, P. Honohan and J. E. Stiglitz (eds), Financial Liberalization: How Far, How Fast? New York, NY: Cambridge University Press, pp. 96-124.

Demirgüç-Kunt, A., Karacaovali B., and Laeven, L. (2008). Deposit Insurance around the World: A Comprehensive Database. In Demirgüç-Kunt, Kane, and Laeven (eds.) Deposit Insurance Around the World: Issues of Design and Implementation, Cambridge, MA: MIT Press.

Demirgüç-Kunt, A. Laeven, L., and Levine, R. (2004). Regulations, Market Structure, Institutions, and the Cost of Financial Intermediation. Journal of Money, Credit, and Banking, 36(3), pp. 593-622.

Diaz-Alejandro, C. (1985). Good-Bye Financial Repression, Hello Financial Crash. Journal of Development Economics, 19, pp. 1-24.

Eichengreen, B., and Rose, A. K. (2004). Staying Afloat When the Wind Shifts: External Factors and Emerging-Market Banking Crises. In Calvo, Dornbusch, and Obstfeld (eds.), Money, Capital Mobility, and Trade: Essays in Honor of Robert A. Mundell. Cambridge, MA: MIT Press.

Fries, S., and Taci, A. (2002). Banking Reform and Development in Transition Economies. European Bank for Reconstruction and Development Working Paper No. 71, available at: http://www.ebrd.com/downloads/research/economics/workingpapers/wp0071.pdf.

Fry, M. (1997), In Favour of Financial Liberalization. The Economic Journal, 107, pp. 754-70.

Furceri, D. and Zdzienicka, A. (2011). The Real Effect of Financial Crises in the European Transition Economies. Economics of Transition, 19: pp. 1-25.

Guiso, L., Sapienza, P., and Zingales, L. (2006). Does Culture Affect Economic Outcomes? Journal of Economic Perspectives, 20(2), pp. 23-48. 
Hartwell, C.A. (2013). Institutional Barriers in the Transition to Market: Examining Performance and Divergence in Transition Economies. Basingstoke: Palgrave Macmillan.

Havrylyshyn, O., and R. van Rooden (2003). Institutions Matter in Transition, But So Do Policies. Comparative Economic Studies, 45, pp. 2-24.

Johnston, R. B., Darbar, S.M., and Echeverria, C. (1999). Sequencing Capital Account Liberalization: Lessons from the Experiences in Chile, Indonesia, Korea, and Thailand. In Johnston and Sundararajan (eds.), Sequencing Financial Sector Reforms. Washington DC: IMF.

Joyce, J.P., and Nabar, M. (2010). Sudden Stops, Banking Crises and Investment Collapses in Emerging Markets. Journal of Development Economics, 90, pp. 314-322.

Kaminsky, G., and Reinhart, C.M. (1999). The Twin Crises: The Causes of Banking and Balance of Payments Problems. American Economic Review, 89, pp. 473-500.

Kose, M.A., Prasad, E., Rogoff, K., and Wei, S-J. (2009). Financial Globalization: A Reappraisal. IMF Staff Papers, 56(1), pp. 8-62.

Laeven, L. (2003). Does Financial Liberalization Reduce Financing Constraints? Financial Management, 32, pp. 5-34.

Laeven, L. and Valencia, F. (2012). Systemic Banking Crises Database: An Update. IMF Working Paper 12/163.

Marshall, M.G., and Jaggers, K. (2012). Polity IV Project: Political Regime Characteristics and Transitions, 1800-2010. Version p4v2010 [Computer File], Center for Systemic Peace, http://www.systemicpeace.org/polity/polity4.htm.

McKinnon, Ronald I. (1980). Financial Policies. In: Cody (ed.), Policies for industrial progress in developing countries. New York: Oxford University Press, pp. 93-120.

Mehrez, G. and Kaufman, D. (2000). Transparency, Liberalization, and Banking Crises. Policy Research Working Paper No. 2286, the World Bank.

Naaborg, I., Scholtens, B., De Haan, J., Bol, H., \& De Haas, R. (2004). How important are foreign banks in the financial development of European transition countries? Journal of Emerging Market Finance, 3(2), pp. 99-123.

Nicoletti, G. and Scarpetta, S. (2003). Regulation, productivity and growth: OECD evidence. Economic Policy, 18(1), pp. 9-72.

Osoian, C., Ioan, L., Corina, G., and Monica, Z. (2008). Determinants of Saving in Transition Economies (1986-2006). Transylvanian Review of Administrative Sciences, 23, pp.74-89. 
Pill, H. R., and Pradhan, M. (1995). Financial Indicators and Financial Change in Africa and Asia. IMF Working Paper No. 95/123, November.

Ranciere, R., Tornell, A., and Westermann, F. (2006). Decomposing the Effects of Financial Liberalization: Growth vs. Crises. Journal of Banking \& Finance, 30, pp. 3331-3348.

Reinhart, C.M., and Rogoff, K.S. (2009). This Time Is Different: Eight Centuries of Financial Folly, Princeton: Princeton University Press.

Rousseau, P., and Wachtel, P. (2011). What is Happening to the Impact of Financial Deepening on Economic Growth? Economic Inquiry, 49, pp. 276-288.

Shehzad, C.T. and de Haan, J. (2009). Financial Reform and Banking Crises. CESifo Working Paper Series No. 2870, available at http://ideas.repec.org/p/ces/ceswps/2870.html.

Tschoegl, A. (2005). Financial Crises and the Presence of Foreign Banks. In Honohan and Laeven (eds.), Systemic Financial Crises: Containment and Resolution. New York: Cambridge University Press.

Weller, C., and Morzuch, B. (2000). International Financial Contagion: Why Are Eastern Europe's Banks Not Failing When Everybody Else's Are? Economics of Transition. 8(4), pp. 639-663.

Yilmaz, R., Yabasakal, A., and Koyuncu, J. (2009). Foreign Bank Presence and Banking Crises in Transition Economies. Paper presented at EconAnadolu 2009: Anadolu International Conference in Economics 17-19, http://econ.anadolu.edu.tr/fullpapers/Yilmaz_Yabasakal_Koyuncu_econanadolu2009.pdf. 